Book Review

\title{
Curriculum Changes in the Visegrad Four: Three Decades After the Fall of Communism by Tomáš Janík, Štefan Porubský, Magdolna Chrappán, Kinga Kuszák
}

\author{
Gabriella Hegedüs ${ }^{1}$ \\ Recommended citation: \\ Hegedüs, G. (2021). Curriculum changes in the Visegrad Four: three decades after the fall by Tomáš Janík, Štefan \\ Porubský, Magdolna Chrappán, Kinga Kuszák. [Review of the book Curriculum changes in the Visegrad Four: three \\ decades after the fall of communism, by Janík, T., Porubský, Š., Chrappán, M., \& Kuszák, K.] Central European Journal \\ of Educational Research, 3(3), 144-146. https://doi.org/10.37441/cejer/2021/3/3/10062
}

Bibliography of the reviewed book: Janík, T., Porubský, Š., Chrappán, M., \& Kuszák, K. (2020). Curriculum changes in the Visegrad Four: three decades after the fall of communism. Waxmann.

\section{Review}

Curriculum Changes in the Visegrad Four: three decades after the fall of communism edited by Tomáš Janík, Štefan Porubský, Magdolna Chrappán and Kinga Kuszák was published by Waxmann in 2020. The book gives a detailed description of the changes and impact that the Visegrad Four Countries have experienced since the fall of communism in 1989 in connection with curriculum development and curriculum policy. The purpose of the book is not only to describe the effects of the changes that have taken place in the curriculum of the countries in the Visegrad Four countries over the last thirty years, but also to give an outline of the characteristics and challenges of curriculum reform. Furthermore, it intends to give the reader an insight into the way that enables curriculum reform and the participants of the process to improve the quality of school and education. Finally, the book aims to contribute to prospective curriculum development and curriculum policy in the Visegrad Four.

Tomáš Janík, a Professor of Education, is the Department Head at the Institute for Research in School Education at Masaryk University, Brno. Štefan Porubský works as a Professor of Education at the Faculty of Education, Matej Bel University in Banská Bystrica. Magdolna Chrappán is an Associate Professor at the Institute of Educational Studies and Cultural Management at the University of Debrecen. Kinga Kuszak works as a university Professor at the Faculty of Educational Studies at Adam Mickiewicz University in Poznan, Poland.

The publication follows a very clear structure, which is consistent with every other section of the book. The Foreword is written by Eliška Walterová, who is a former head of the Institute for Research and Development of Education at Charles University in Prague. She starts with explaining the phenomenon of the Visegrad Group, and the process of how, from their initial purpose of helping the region to become stable and to integrate into Europe, these countries have become a place for regular political summits. She gives a detailed explanation of the historical background, going back to the end of the 1980s when "the geopolitical map of the world" (Walterová in Janík et al.,2020, page 7.) changed to a great extent, showing how Central Europe has become part of the political scene. She reflects on V4 activities and points out that while the Visegrad Group has not gained a legal status that is recognized internationally, or by a specific institutional structure, it is a "remarkable example of the human dimension of European identity" (Walterová in Janík et al., 2020, page12.). Finally, she describes that although educational changes have taken place and have attempted to follow trends in Western democratic countries, apparently the changes mostly concern educational policy and strategies rather than the change in teaching practice.

Chapter One, the Introduction, is written by Tomáš Janík and Štefan Porubský and is titled Curriculum changes in the Visegrad Four countries three decades after the fall of communism. The authors mention the

\footnotetext{
${ }^{1}$ University of Debrecen, Debrecen, Hungary; hegedus.gabriella@arts.unideb.hu
} 
fact that although all four countries have experienced similar educational changes during this period, they find there is no systematic review available yet, therefore the authors try to fill the gap and describe curriculum changes in the V4 countries in detail.

Chapter Two, titled Curriculum Changes in Hungary: Centralisation and decentralisation in the curriculum policy, is written by Magdolna Chrappán and Rita Bencze, and deals with the description of curriculum changes and curriculum developments after the fall of communism in Hungary. An insight is given into the characteristics of the said changes that have been made over thirty years in the curriculum, as well as the regulatory structure. The authors emphasize that albeit the constant changes, it has been quite impossible to carry out educational reform as the aforementioned modifications have not always been consistent with the modern educational trends. Instead, they have rather been influenced by the educational policy of the government. What seem to have been stable though are the three types of curricula - the upper level National Core Curriculum, the middle level Framework Curriculum and the lower level curriculum - that have been used since 1989 and which are explained in detail. Depending on the direction of centralization or decentralization, second-, or third-level curricula have been in use in Hungary's educational reform. At the end of the chapter, the authors conclude that in order to have a content-based reform in curriculum development, it is vital that both teachers and institutions are given "effective pedagogical freedom" (Chrappán in Janík et al, 2020, page60).

Chapter Three, titled Curriculum Changes in Poland: School education between reforms is written by Kinga Kuszak, Katarzyna Sadowska, Natalia Kysz-Sokalska and Agnieszka Bojarczuk-Tüncer, and it provides the reader with an insight into how Poland set out to prepare the younger generation for the challenges and the job market of the 21 st century. During a period characterised by changes in the economy, in society as well as the political system, the country aimed to carry out a radical reform of the education system. This aim was further asserted when joining European Union. The reform consisted of three phases. The first phase was the Transformation, which took place between 1989-1998, and aimed at making the reform a national priority. In 1996, the Polish government announced the development of a new curriculum and the level of education, according to which a total change would take place in the educational system. The second stage was the Fundamental reform and took place between 1999-2016. Its focus was to improve the quality of education and to reduce inequality of educational opportunities by making secondary and higher education available for everyone. In 2009, the core curriculum was revised: it was not only made more comprehensive than the one before, but also had the intention of dealing with the objectives of general education. The third stage, the current reform, has been taking place since 2017 and it aims to change the structure of education with an emphasis on the development of the structure of the school system in general. The author recommends that although the development of the school system in Poland has at times been controversial, it is still vital to establish the friendliest and most modern schools possible, which prepare students for the competences of the 21 st century.

Chapter Four, titled Curriculum Changes in the Czech Republic: Beyond Implementation is written by Tomáš Janík, Karolína Dundálková and Jan Tupy. It gives a summary of the development of curriculum changes and reforms in the Czech school system that have taken place since 1990. First of all, the authors examine important strategic papers that had an important role in identifying the shortcomings of the school system as well as proposing future changes. Then the authors proceed to describe the four stages of educational reform after the Velvet Revolution. During the first stage of deconstruction and stabilization between 1990-1998, the target of the reform was to abandon the principles and ideologies characterising the period before 1989. They aimed to create freedom in education so that students were able to choose schools and higher institutions freely. The second period of reform was characterised by reconstruction. The main areas of concern were the future development and implementation of a national educational system and the development of a specific curriculum. The third stage was that of implementation and revision of the reform and it took place between 2006-2013. Though there seemed to be problems regarding implementation as there was no umbrella education policy, and indicators of achievement were also missing, it was still supported by the government. The final stage has been taking place since 2013, and the focus has shifted from the reform of the curriculum to the inequality in education. Strategy 2020, a policy document was made by MEYS in 2014, titled Strategy for Education Policy of the Czech Republic until 2020, which highlights recommendations for future developments of the school system. Apart from the reduction of inequality, it also sets high quality teaching and teacher training as an objective.

Chapter Five, titled Curriculum Changes in the Slovak Republic: A country waiting for major reform is written by Štefan Porubský, Beata Kosová and Petra Fridrichová, and it is about the review of the development of the educational system. Along with present changes, the authors describe in detail the four phases of transformation typical for post-Communist countries. First of all, they start out with the deconstruction period 
between 1989-1992, when, like Czech reform, the main aim was the removal of old ideologies related to the Communist era. Then the reader is given an insight into the period of stabilization that took place in the second phase of transformation between 1992-2001. This was a controversial period, as albeit the introduction of educational innovations on the part of teachers and non-governmental organisations, rigidity could be experienced by the state, whose main objective was the stabilisation of the existing system. The third phase of transformation was characterised by reconstruction between 2001-2008. The authors point out that the Slovakian method of reconstructing the system differed from the usual way of transformation beginning with the adoption of a national educational development programme and implementation of reforms. Instead, Slovakia decided to carry out a reform of educational management. The tasks for the fourth period of transformation after 2008 have been to implement changes, stabilise the educational system and set aims as well as prospects for further reform and Learning Slovakia, a complex programme covering all levels of educational reform was introduced. However, in 2017, with the change of leadership, the Ministry of Education decided to carry out a new type of reform, therefore that reform implementation is still in progress today in Slovakia.

The last chapter, Chapter Six, titled Curriculum changes in the V4 countries three decades after: A closer look, the editors of the publication provide an excellent summary for the case studies of the V4 countries. They take a look at the characteristics of the changes in the curriculum, look at the change towards decentralisation of curriculum development, examine the difficulties of implementation of curriculum reform and recommend future prospects.

The purpose of this well-structured, clear and informative collection of curriculum development and matters of educational consideration is to highlight the developments that have been made to curriculum policy in the Visegrad Four countries over the past thirty years. Although it becomes obvious to the reader that all of the Visegrad countries have been trying hard to reform their eductational system, unfortunately none of them have managed to make a radical change or to realize their initial objective. Due to the rich historical content of the book, the target audience, who will find the publication most useful, are students, and educators as well as researchers who wish to further investigate, either the educational situation of the Visegrad Four countries or of countries with a similar educational system.

Acknowledgments: We thank Victoria Congdon for the English language editing. Her work was supported by the Central Connecticut State University, America.

\section{References}

Janík, T., Porubský, Š., Chrappán, M., \& Kuszák, K. (2020). Curriculum changes in the Visegrad Four: three decades after the fall of communism. Waxmann.

(C) 2021 by the authors. Submitted for possible open access publication under the terms and conditions of the Creative Commons Attribution (CC BY) license (http://creativecommons.org/licenses/by/4.0/). 